\title{
Correlation between Physical Workload and Musculoskeletal Disorders Complaints among Nurses at Hospital
}

\author{
Hubungan Beban Kerja Fisik dengan Keluhan Gangguan Muskuloskeletal pada \\ Perawat di Rumah Sakit
}

\author{
Heni Fa'riatul Aeni, Lilis Banowati, Tuti Nur'alinda \\ Public Health Department, Sekolah Tinggi Ilmu Kesehatan Cirebon \\ Jalan Brigjend Dharsono No.12b, Kertawinangun, Kedawung, Cirebon, West Java, 45153 Indonesia
}

\begin{abstract}
Introduction: Musculoskeletal disorders complaints occur due to excessive muscle contraction, excessive workloads and monotonous movements such as when nurses perform various nursing task such as moving patients, carrying patients from bed to wheelchair, awkward posture during infusion placement. This study aims to determine the correlation between physical workload and musculoskeletal disorders complaints among nurses at Regional General Hospital (RSUD) of Indramayu District in 2019. Methods: The design of this study uses quantitative with cross sectional. The method of data collection was crried by means of interview using the Nordic Body Map (NBM) questionnaire and observing the pulse calculation manually using a watch. Among the populations of 348 nurses, the samples of 75 nurses were selected based on the accidental sampling method. Statistical test used the chi-square test with a confidence level of $95 \%(\alpha=0.05)$. Results: The study findings showed that most of 40 nurses who had heavy physical workload, 35 nurses (87.5\%) had high musculoskeletal disorders complaints and 5 nurses (12.5\%) had moderate musculoskeletal disorders complaints. On the other hand, of the 35 nurses who had moderate physical workload, 26 nurses $(74.3 \%)$ experienced moderate musculoskeletal complaints and 9 nurses $(25.7 \%)$ had high musculoskeletal disorders complaints. Chi-Square test results obtained $\mathrm{p}$ value $=0.000(\mathrm{p}<0.05)$. Thus, it can be concluded that there was a significant correlation between physical workload and musculoskeletal disorders complaints among nurses. Conclusion: The heavier the physical workload, the higher the musculoskeletal disorders complaints among nurses.
\end{abstract}

Keywords: musculoskeletal disorders, nurses, physical workload

\begin{abstract}
ABSTRAK
Pendahuluan: Keluhan gangguan muskuloskeletal dapat muncul akibat kontraksi otot yang berlebihan, beban kerja yang terlampau berat dan gerakan monoton seperti ketika perawat melakukan berbagai tugas keperawatan yaitu memindahkan pasien, membawa pasien dari tempat tidur untuk didudukkan di kursi roda, postur canggung selama pemasangan infus. Tujuan dari penelitian ini adalah untuk mengetahui Hubungan antara beban kerja fisik dan keluhan gangguan muskuloskeletal pada perawat di Rumah Sakit Umum Daerah (RSUD) kabupaten Indramayu pada Tahun 2019. Metode: Rancangan penelitian ini menggunakan penelitian kuantitatif dengan rancangan cross sectional, metode pengumpulan data dilakukan melalui wawancara dengan menggunakan kuesioner Nordic Body Map (NBM) dan melakukan perhitungan denyut nadi menggunakan jam tangan. Dari populasi 348 perawat diperoleh sampel sebanyak 75 perawat yang dipilih berdasarkan metode accidental sampling. Uji statistik menggunakan uji chi square dengan tingkat kepercayaan 95\% (a 0,05). Hasil: Hasil penelitian menunjukkan bahwa dari 40 perawat yang memiliki beban kerja fisik berat sebanyak (87,5\%) mengalami keluhan muskuloskeletal tinggi dan (12,5\%) mengalami keluhan muskuloskeletal sedang, sedangkan dari 35 perawat yang memiliki beban kerja fisik sedang terdapat (74,3\%) mengalami keluhan muskuloskeletal sedang dari $(25,7 \%)$ mengalami keluhan muskuloskeletal tinggi. Hasil uji Chi-Square memperoleh $p$ value $=0,000(p<0,05)$. Maka dapat disimpulkan bahwa terdapat hubungan yang signifikan antara beban kerja fisik dengan keluhan muskuloskeletal pada perawat. Simpulan: Semakin berat beban kerja fisik maka semakin tinggi keluhan gangguan muskuloskeletal pada perawat.
\end{abstract}

Kata kunci: beban kerja fisik, gangguan muskuloskeletal, perawat

(C2020 IJOSH. Open access under CC BY NC-SA license doi: 10.20473/ijosh.v9i1.2020.88-94. Received December 05, 2019, received in revised form April 14, 2019, Accepted April 29, 2020, Published: April 2020 


\section{Author for Correspondence:}

Heni Fa'riatul Aeni, S.KM., M.KM

Email: henifariatulaeni80@gmail.com

Telephone: +6285321338538

\section{INTRODUCTION}

Workers need to comprehend ergonomics to prevent the Musculosceletal Disorders issues, so they can do their jobs according to the ergonomic standard position of the body. If the application of ergonomics is not done properly, there will be ergonomic risks due to work in the form of Musculosceletal Disorders (MSDs) which are mostly caused by incorrect positions and postures during work activities (Nurmianto, 2006).

Musculoskeletal disorders (MSDs) are complaints of the skeletal muscles received by person ranging from minor to severe pain complaints. A semi-quantitative method evaluates the symtoms of muscle fatigue in most of body parts through an assessment based on the level of effort a work has, the duration of continuous effort, and the frequency of effort. If there is muscle fatigue, injuries will be easier to occur. Parts of the body that have the symtoms to experience muscle fatigue are classified into low, moderate, and high levels so that treatment priorities can be identified to prevent muscle injury. A repeated static burden on the muscles over a long period of time may cause complaints in the form of damage to the joints, tendons, and ligaments (Riyadin, Suharyanto and Tana, 2008).

Factors causing musculoskeletal grievance are reasonable muscle tention, for example lifting, pushing, pulling and holding substantial burdens. Other causes include repetitive activities, unnatural work attitudes, stresses, vibrations, microclimates, cause of the combination, and individual characteristics for example, age, sex, smoking propensities, physical wellness, physical capacity, also body weight and height (Tarwaka, 2010).

Outstanding task at hand can be characterized as a distinction between the limit or capacity of laborers and work requests (Tarwaka, 2010). Physical workload requires muscle, heart and lung works, such that if the physical workload is high then the work of the muscles, heart and lungs will be increasingly high, and vice versa (Maharja, 2015).

Nurses' daily duties in handling patients such as moving the patients from their bed to the wheelchair, repositioning them in bed, mobilizing from the toilet to the seat, moving patients from the seat to the bed, moving the patient from the tub to the chair, lifting the patient in bed, preparing the bed with the patient on top of it, and moving the patient between beds are the examples of risk factors for musculoskeletal disorders complaints. The awkward posture of the nurses in doing the work uses a lot of bowing and contorting the body, particularly around the lower bones (Menzel, Nancy, 2004).

Based on the results of a survey conducted by the Department of Health in the profile of health issues occurred in 2005, whereas it was shown that about $40.5 \%$ of illnesses faced by workers were related to their work. According to a study among 482 employee in 12 districts in Indonesia, health issue incident by workers were usually in the form of MSDs (16\%), cardiovaskuler (8\%), neurological disorders $(6 \%)$, respirator disorders (3\%) and Eart Noise Throat (ENT) disorder (1.5\%) (Depkes RI, 2009) (Sumiati, 2007).

The results of Sweden Statistics Agency in 2006 it was reported that the most prominent musculoskeletal issues among medical attendants were low back pain (56\%), shoulders, arms and fingers $(24 \%)$, neck (6\%), and legs (14\%) pain. Furthermore, a study conducted by Yun in 2010 in Korea concluded that $(90.3 \%)$ of nurses in a month had musculoskeletal complaints at least once $(21.9 \%$ constantly, $40.7 \%$ once every week and $27.7 \%$ once per month) (Manengkey, Josephus and Pinontoan, 2016). The results of those studies evidenced that many nurses leaved their jobs both permanently and temporarily due to musculoskeletal disorders (Menzel, Nancy, 2004)(Habibi, 2015).

The World Health Organization (WHO) estimates that the prevalence of MSDs disorders were almost $(60 \%)$ of all occupational diseases. The European Commission of Trustees estimates that MSDs case causes (49.9\%) absence from work for more than three days and (60\%) cases of permanent inability to work. In Argentina, after reported 2010 22,013 cases of occupational diseases were reported, and MSDs were the most common events (Sang, 2013).

A study conducted by Primalia Sukma Putri among workers at Nganjuk shoe factory in 2019 found a $p$ value of 0.009 which meant that there was a significant correlation between physical workload and subjective Musculoskeletal Disorders (MSDs) complaints and obtained a contingency coefficient value of 0.452 ; the heavier the workload, the higher the severity of subjective musculoskeletal complaints among workers (Putri, 2019). 
One of the main causes of human error that causes a decrease in quality and work efficiency is inappropriate workload for employees. The workload element is a key factor for reducing work-related accidents and injuries as well as management losses and costs (Khandan et al., 2018).

Regional General Hospital (RSUD) of Indramayu District is the largest hospital in Indramayu District which has 348 nurses. The results of a preliminary study conducted on May 17, 2019 using interviews on 10 nurses showed that 7 nurses experienced musculoskeletal pain complaint lowe, fatigue and, dizziness due to repeated work attitude activities they carried out including bending, rotating the body, such as lifting the patient, moving the patient, placing an IV tube, giving drugs by injection, and others. Furhermore, 3 nurses experienced tingling but only for a while and it resolved after a rest.

This study aims to determine correlation between physical workload and musculoskeletal disorders complaints among nurses at Regional General Hospital (RSUD) of Indramayu District in 2019.

\section{METHODS}

This is a cross sectional design to assess the correlation between the independent (physical workload) and dependent variables (musculosceletal disorders comlpaints). The populations in this study were all 348 nurses at Regional General Hospital (RSUD) of Indramayu District. However, only 75 nurses were involved in this study using accidental sampling technique.

The instrument used for data collection in this study was the Nordic Body Map (NBM) questionnaire with was carried out using interview, NBM measurement results are devided into three categories, low, moderate, high. Whereas the at the wrist using a stopwatch. The formula for Physical workload based on pulse is as follows (Tarwaka, 2015).

The pulse measurement was carried out for 15 seconds during work and 15 seconds at rest. Based on the provision, the maximum pulse rate for men is $(220-$ age $)$ and women is (200-age). The result of calculation of $\% \mathrm{CVL}$ was then clasified into light workload of $75-100$, moderate workload of $100-$ 125 , heavy workload of $125-150$.

Data analysis performed in this study consisted of univariate and bivariate analysis.
Univariate analysis was used to represent to frequency distribution of physical workload and musculoskeletal disorder complaints. Bivariate analysis was used to examine the correlation between both variables. The statistical test utilized here was Chi-Square with a certainly level of $95 \%$ ( $p$ value > 0.05 ). This study has truly obtained ethical approval from the RSD Gunung Jati Cirebon of Medicine Ethics Committee (No.: No.043/LAIKETIK/ KEPKRSRSGJ/VIII/2019).

\section{RESULTS}

\section{Physical Workload}

The analysis results on physical workload among 75 nurses at Regional General Hospital (RSUD) of Indramayu District are presented in Table 1 below:

The results in Table 1 showed that among 75 nurses, majority or $40(53.3 \%)$ of the respondents had heavy physical workload and 35 (46.7\%) had moderate physical workload while none of the nurses had a light physical workload $0(0 \%)$.

\section{Musculoskeletal complaints}

The analysis results on musculoskeletal complaints among 75 nurses at Regional General Hospital (RSUD) of Indramayu District are

Table 1. Frequency Distribution of Physical Workload among Nurses at RSUD of Indramayu District in 2019

\begin{tabular}{ccc}
\hline Workload & Frequency (n) & Percentage (\%) \\
\hline Light & 0 & 0 \\
Moderate & 35 & 46.7 \\
Heavy & 40 & 53.3 \\
\hline Total & 75 & 100 \\
\hline
\end{tabular}

Table 2. Frequency Distribution of Musculoskeletal Disorders Complaints among Nurses at RSUD of Indramayu District in 2019

\begin{tabular}{ccc}
\hline $\begin{array}{c}\text { M u s c u l o s ke l e t a l } \\
\text { Complaints }\end{array}$ & $\begin{array}{c}\text { Frequency } \\
\text { (n) }\end{array}$ & $\begin{array}{c}\text { Percentage } \\
\text { (\%) }\end{array}$ \\
\hline Low & 0 & 0 \\
Moderate & 31 & 41.3 \\
High & 44 & 58.7 \\
\hline Total & 75 & 100 \\
\hline
\end{tabular}


Table 3. Correlation between Physical Workload and Musculoskeletal Disorders Complaints among Nurses at RSUD of Indramayu District in 2019

\begin{tabular}{|c|c|c|c|c|c|c|c|}
\hline \multirow{3}{*}{$\begin{array}{l}\text { Physical } \\
\text { Workload }\end{array}$} & \multicolumn{4}{|c|}{$\begin{array}{c}\text { M u s c u l o s k e l e t a l } \\
\text { Complaints }\end{array}$} & \multirow{2}{*}{\multicolumn{2}{|c|}{ Total }} & \multirow{3}{*}{$\begin{array}{l}P \\
\text { value }\end{array}$} \\
\hline & \multicolumn{2}{|c|}{ Moderate } & \multicolumn{2}{|c|}{ High } & & & \\
\hline & $\mathrm{n}$ & $\%$ & n & $\%$ & $\mathbf{N}$ & $\%$ & \\
\hline Moderate & 26 & 74.3 & 9 & 25.7 & 35 & 100 & \\
\hline Heavy & 5 & 12.5 & 35 & 87.5 & 40 & 100 & 0.000 \\
\hline Total & 31 & 41.3 & 44 & 58.7 & 66 & 100 & \\
\hline
\end{tabular}

presented in the Table 2. The results in Table 2 showed that among 75 nurses, the majority or 44 $(58.7 \%)$ had complaints in high of pain and 31 $(41.3 \%)$ had complaints in moderate musculoskeletal disorders. While none of the nurses had complaints in low musculoskeletal disorders.

\section{Correlation between Physical Workload and Musculoskeletal Complaints among Nurses at Regional General Hospital (RSUD) of Indramayu District}

The results on the correlation between physical workload and musculoskeletal disorders complaints among 75 nurses at Regional General Hospital (RSUD) of Indramayu District are presented in Table 3.

Based on the results presented in Table 3, of the 40 nurses who had heavy physical workload, 35 nurses $(87.5 \%)$ had high musculoskeletal disorders complaints and 5 nurses (12.5\%) had moderate musculoskeletal disorders complaints. On the other hand, of the 35 nurses who had moderate physical workload, 26 nurses (74.3\%) experienced moderate musculoskeletal complaints and 9 nurses $(25.7 \%)$ had high musculoskeletal disorders complaints. ChiSquare test results obtained $\mathrm{p}$ value $=0.000(\mathrm{p}$ $<0.05$ ). Thus, we might conclude that there was a significant correlation between physical workload and musculoskeletal disorders complaints among nurses.

\section{DISCUSSION}

\section{Physical Workload}

The study results showed that 40 nurses $(53.3 \%)$ had a heavy workload, whereas 35 nurses $(46.7 \%)$ experienced moderate workloads. Based on study results, most nurses experienced heavy workload. The results might due to this study was conducted in the morning shift which has quite heavy activity compared to the afternoon shift or night shift. The work tasks carried out by nurses in treating patients were varied from moving the patient, giving the drug through an IV tube, changing the IV fluids, taking the patient to the radiology room using a wheelchair and others until, lifting heavy loads, and those duties are the biggest risk factors for musculoskeletal exposure. Every workload faced by a nurse must be balanced with physical ability, cognitive as well as the limitations of human who gets it (Tarwaka, 2010).

In general, manual handling task such as lifting, lowering, pushing, pulling and sustained exertion which uses excessive force are complained by the workers. Physical workload can be defined as any work that involve energy in human muscles that we know has a function as the source of vitality. Physical work can also called as 'manual activity' in which the execution of work will depend entirely on human exertion that acts as a source of energy and control of work (Tarwaka, 2015).

Overall, a nurse actually not only bears physical workload, but also social and mental workload too. The nature of the varied workload as nurses in hospital deals with patients of all category, males, females and of different age and body weight which requires exertion. However, considering that the women physical capabilities are only $2 / 3$ that of male, the nurses' workload would have fall in the heavy workload category. This is further affected by the individual factors such as age, gender, nutritional status, physical fitness and body size of the nurses (Tarwaka, 2010). This was likely to cause the physical workload of most respondents $(53.3 \%)$ to be in the heavy category. High work demands are often unavoidable which may cause workers to experience pain in their limbs (Aeni, 2017). Efforts to reduce workload can be done by planning and/ or designing a tool that can minimize complaints of inappropriate workload.

\section{Musculoskeletal Disorders Complaints}

The results showed that majority of nurses or $44(58.7 \%)$ nurses had musculoskeletal disorders complaints with a high category whereas $31(41.3 \%)$ were in the moderate category of musculoskeletal complaints. This indicated that most nurses experienc musculoskeletal complaints. The results is in line with a study conducted by Kamaraguruparan 
Gopal which showed that most nurses had a musculoskeletal disorders complaints, complaints that were often felt were pain in the lower back and wrist (Gopal, Thomas and Sreedharan, 2012). The results of those studies evidenced that many nurses leaved their jobs both permanently and temporarily due to experiencing musculoskeletal disorders (Menzel, Nancy, 2004) (Habibi, Taheri and Hasanzadeh, 2015).

Musculoskeletal disorders (MSDs) are defiend as complaints on the parts of the skeletal muscles experienced by a person ranging from minor to severe complaints. In the event that the muscles sustain exertion more than once over a significant period of time, it will cause damage to the joints, tendons, and ligaments. Complaints regarding this damage are usually defined as complaints of musculoskeletal disorders (MSDs) or injuries onto the musculoskeletal system (Tarwaka, 2014).

Awkward postures are postures when body parts detached from the body gravitation, for example,arms and hands raising, bowing, head lifting, and many more. In addition, the more detached the body position from the body gravitation, the higher the complaints of disorders (Grandjean, 1993). Most nurses have a musculoskeletal disorders, complaints are often felt in the lower back and wrists. Most of the musculoskeletal complaints which were felt in the heavy category were likely due to sampling done to nurses who worked in the morning shift since there were more/higher rates of physical activities, so that musculoskeletal complaints would be felt more severe.

Musculoskeletal complaints are caused by increased physical or muscular work, which cause muscle pain, aches or tremors. Musculoskeletal complaints are characterized by a decreased ability of muscles to lift weights, slower contraction and relaxation and longer time spacing between stimulation and the start of contraction (Widyastuti, 2010).

Muscle complaints can be divided into 2 groups: temporary complaints and persistent complaints. The level of acute musculoskeletal pain occurs in less than three months, and will heal after receiving treatment/rest at home for 4-6 weeks. Chronic level occurs in more than 3 months and often recur. (Tarwaka, 2015).

MSDs is a major cause of absenteeism, work limitations, or even the need to change jobs, disability affecting performance at work, general well-being and quality of life. It was estimated that
$3.5 \%$ of nurses are leaving their profession due to back pain (Anap, 2013)(Moussa M, 2015)

\section{Correlation between Physical Workload and Musculoskeletal Disorders Complaints among Nurses}

The results presented in Table 3, 40 nurses who had heavy physical workload $(87.5 \%)$ had high musculoskeletal disorders complaints and 5 nurses $(12.5 \%)$ had moderate musculoskeletal disorders complaints. Statistical test results obtained $\mathrm{p}$ value $=0.000(\mathrm{p}<0.05)$, thus we might conclude that there was a significant correlation between physical workload and musculoskeletal complaints among nurses. The finding is in line with the study conducted by Primalia Sukma Putri among workers at Nganjuk shoe factory with a $\mathrm{p}$ value of 0.009 , which meant that there was a significant correlation between physical workload and subjective Musculoskeletal Disorders (MSDs) complaints, the heavier the workload, the higher the severity of subjective musculoskeletal complaints among workers (Putri, 2019). Likewise, the results of a study conducted by Aulia Tjahayuningtyas found that there was a correlation between workload and musculoskeletal disorders (Aulia, 2019). The result of a study most of Tanta University Hospitals nurses reported Work related MSDs at different body sites, where the low back being harmed most frequently(Hanaa A, Zayed. Shimaa M, Saied. Rania M, El-sallamy. and Walaa M, 2019).

In general, excessive stretching of muscles is often complained by workers who conduct the activities of lifting, pushing, pulling and holding heavy loads. This excessive stretching of muscle occurs because the movement of energy required exceeds the optimum strength of the muscle. If excessive muscle stretching always occurs, it can increase the risk of muscle complaints, and can even lead to skeletal muscle injury (Tarwaka, 2015).

By pointing on the results of the study, we could see that there was a significant correlation between physical workload and musculoskeletal complaints due to excessive muscle contractions caused by excessive workload and static movements on muscles over a long time such as when nurses perform nursing actions such as moving the patient, carrying the patient in a wheelchair, too bent work position during infusion. Especially this condition happened in the morning shift because of more activities than the afternoon and night shift. Musculoskeletal disorders and workloads can be 
prevented through technical and administrative controls to control workload on workers. Both macro and micro approaches can be considered in the correction program (Khandan et al., 2018).

Physical workload not only causes musculoskeletal disorders but can also result in fatigue. This can causes in decreased work productivity and accident.

The cause of musculoskeletal complaints disorders are not only physical workload, but there are still many other factors. Individual factors become one of the factors which cause the emergence of musculoskeletal disorders complaints including age, sex, smoking propensities, physical wellness, physical capacity, also body weight and height (Tarwaka, 2010). Nurses at Regional General Hospital of Indramayu District were mostly female and this was likely to cause the physical workload of most respondents to be was in the heavy category since female muscle strength is lower than men. Thus, is necessary to adjust the workload with the capacity or ability of a person so that the workload is not considered heavy and musculoskeletal disorders complaints can be lower.

The findings of this study showed that a combination of ergonomic interventions, including engineering and organizational interventions along with stakeholder's involvement, reduce physical risk factors. The effects of interventions on ultimate MSDs were ambiguous, but the participants reported fewer MSDs symptoms after intervention (Roquelaure, 2020).

The heavier the physical workload, the higher the musculoskeletal disorders complaints among nurses. The Hospital should add one nurse per room in the morning shift and provide physical fitness services held in routine gymnastics once a week. For the nursing profession, it is expected to correct working posture to decrease musculoskeletal disorders complaints namely not too bent the body while working, resting on both feet, and not doing too flexed movements at other angles of the body, doing regular exercise once a week such as jogging or gymnastics and doing muscle stretching after performing nursing actions or when they feel fatigue.

\section{CONCLUSIONS}

By referring to the analysis conducted, we might conclude that there is a significant correlation between physical workload and musculoskeletal disorders complaints among nurses. The heavier the physical workload, the higher the musculoskeletal disorders complaints among nurses.

\section{ACKNOWLEDGEMENT}

The authors would like to acknowledge director RSUD Indramayu for the permission to carry out research and all nurses who have participated as respondent in this study. In addition, the authors are thankful to public health department STIKes Cirebon.

\section{REFERENCES}

Aeni, H. F. A. (2017) 'Hubungan Sikap Kerja Duduk dengan Keluhan Nyeri Punggung Bawah pada Pekerja yang Menggunakan Komputer', Jurnal Kesehatan, 8(1), pp. 887-894.

Anap, D. I. C. and R. K. (2013) 'Work related musculoskeletal disorders among hospital nurses in rural Maharashtra', Int J Res Med Sci, 1(2), pp. 101-107.

Aulia, T. (2019) 'Faktor yang Mempengaruhi Keluhan Muskuloskeletal Disorders (MSDs) pada Pekerja Informal', The IndoAulia, T. (2019) 'Faktor yang Mempengaruhi Keluhan Muskuloskeletal Disorders (MSDs) pada Pekerja Informal', The Indonesian Journal of Occupational Safety and Health, 8(1), pp. 1-10.nesian Journal of Occupational Safety and Health, 8(1), pp. 1-10.

Depkes RI (2009) Ergonomi. Jakarta: Pusat Kesehatan Kerja, Depkes RI.

Gopal, K., Thomas, M. and Sreedharan, J. (2012) 'Work-related Musculoskeletal Disorders (WMSD) in Hospital Nurses: Prevalence and Coping Strategies', in 4th Annual Scientific Meeting of Gulf Medical University. Ajman: Gulf Medical Journal, pp. 159-163.

Grandjean, E. (1993) 'Fitting the Task to the Man: an Ergonomic Approach', in 4. London: Taylor \& Francis Ltd.

Habibi, E. M. R. T. A. H. (2015) 'Relationship between mental workload and musculoskeletal disorders among Alzahra Hospital nurses', Iranian Journal of Nursing and Midwifery Research, 20(1), pp. 1-6.

Hanaa A, Zayed. Shimaa M, Saied. Rania M, Elsallamy. and Walaa M, S. (2019) 'Work-Related Musculoskeletal Disorders among nursing staff of Tanta University Hospitals: pattern, risk factors, 
and coping strategies', The Egyptian Journal of Community Medicine, 37(4).

Khandan, M. et al. (2018) 'Subjective Workload and Musculoskeletal Disorders among Workers of a Manufacturing Company in Iran', Biotech Health Sciences, 5(1), pp. 1-6.

Maharja (2015) 'Analisis Tingkat Kelelahan Kerja Berdasarkan Beban Kerja Fisik Perawat di Instalasi Rawat Inap RSU Haji Surabaya', The Indonesian Journal of Occupational Safety and Health, 4(1), pp. 93-102.

Manengkey, O. K., Josephus, J. and Pinontoan, O. R. (2016) Analisis Faktor-faktor Resiko Yang Berhubungan dengan Keluhan Muskoskeletal Pada Perawat Instlasi Gawat Darurat (IGD) RSUP Prof Dr. R. D. Kandou Manado. Scientific Article. Manado: Faculty of Public Health, Universitas Sam Ratulangi.

Menzel, Nancy, N. B. S. B. T. N. A. (2004) 'The physical workload of nursing personnel: association with musculoskeletal discomfort', International Journal of Nursing Studies, 41(8), pp. 859-867.

Moussa M, E.-E. H. H. and E.-M. R. (2015) 'Low Back Pain and Coping Strategis among nurses in Port Said City, Egypt', Journal of Nursing Education and Practice, 5(7), pp. 55-62.

Nurmianto, E. (2006) Ergonomi : Konsep Dasar dan Aplikasinya. Jakarta: Candimas Metropole.

Putri, P. S. (2019) 'Hubungan beban kerja fisik dengan Keluhan Musculoskeletal Disorders pada Pekerja di Pabrik Sepatu Nganjuk', Jurnal Keperawatan Muhammadiyah, 4(1), pp. 63-67. doi: DOI: $10.30651 / \mathrm{jkm} . \mathrm{v} 4 \mathrm{i1} .2044$.

Riyadin, W., Suharyanto, F. and Tana, L. (2008) 'Keluhan Nyeri Muskuloskeletal pada pekerja Industri di kawasan industri di Kawasan Industri Pulo Gadung Jakarta', Majalah Kedokteran Indonesia, 58(1), pp. 8-12.

Roquelaure, M. Z. N. B. J.-C. S. G. H. Y. (2020) 'Ergonomics interventions to reduce musculoskeletal risk factors in a truck manufacturing plant', International Journal of Industrial Ergonomics, 75.

Sang, A., Djajakusli, R. and Russeng, S. S. (2013) Hubungan Risiko Postur Kerja Dengan Keluhan Musculoskeletal Disorders (MSDs) Pada Pemanen Kelapa Sawit di PT. Sinergi Perkebunan Nusantara 2013. Scientific Articles. Makasar: Faculty of Public Health, Universitas Hasanudin.

Sumiati (2007) Analisis Risiko Low Back Pain (LBP) pada Perawat Unit Darurat dan Ruang Operasi di RS Prikasih Jakarta Selatan 2007. Skripsi. Jakarta: FKM UI.

Tarwaka (2010) Ergonomi Industri Dasar-dasar Pengetahuan dan Aplikasi di Tempat Kerja. Surakarta: Harapan Press.

Tarwaka (2015) Ergonomi Industri. Dasar-dasar Pengetahuan Ergonomi dan Aplikasinya di Tempat Kerja. Solo: Harapan Press.

Tarwaka, dkk (2014) Ergonomi Untuk Keselamatan, Kesehatan Kerja, dan Produktivitas. Surakarta: UNIBA Press.

Widyastuti (2010) Faktor yang Berhubungan dengan Keluhan Muskuloskeletal pada Buruh Angkut Sayur di Jalan Pedamaran Pasar Johar 2009. Skripsi. Semarang: Fakultas Ilmu Keolahragaan UNNES. 